\title{
Climate Change Adaptation Through Sustainable Water Resources Management in Kenya: Challenges and Opportunities
}

\author{
Shilpa Muliyil Asokan, Joy Obando, Brian Felix Kwena, and \\ Cush Ngonzo Luwesi
}

\section{Contents}

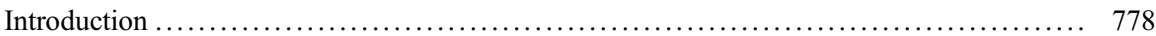

East African Community and Climate Change Impacts .......................... 779

Kenya: Country Climate and Water Profile, Climate Change Impacts ................. 780

Wise Water Management Toward Climate Change Adaptation ........................ 781

Climate Resilience Through Water Management ................................ 782

Water: A Cross-Cutting Factor in Agenda 2030 SDGs ............................ 784

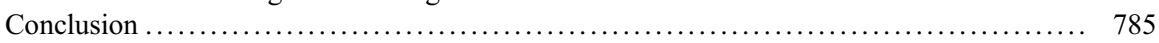

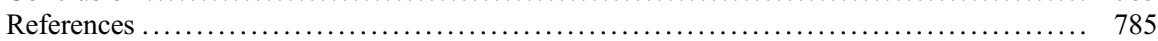

\section{Abstract}

Water is the medium through which society experiences the most dramatic and direct manifestations of climate change. At the same time, water has a critical

This chapter was previously published non-open access with exclusive rights reserved by the Publisher. It has been changed retrospectively to open access under a CC BY 4.0 license and the copyright holder is "The Author(s)". For further details, please see the license information at the end of the chapter.

S. M. Asokan $(\bowtie)$

Climate Change and Sustainable Development, The Nordic Africa Institute, Uppsala, Sweden e-mail: shilpa.asokan@nai.uu.se

J. Obando

Department of Geography, Kenyatta University, Nairobi, Kenya

e-mail: obandojoy@yahoo.com; obando.joy@ku.ac.ke

B. F. Kwena

Kenya Water for Health Organization, Nairobi, Kenya

e-mail: felix.brian@kwaho.org

C. N. Luwesi

University of Kwango, Kenge, Democratic Republic of Congo

e-mail: cushngonzo@gmail.com 
role to play in climate change adaptation and is central towards achieving Africa Water Vision 2025, and the targets set for the 2030 Agenda for Sustainable Development as well as the Kenya Vision 2030. There are fundamental challenges that need to be addressed in order to achieve sustainable water resources management, mainly, the inherent uncertainty associated with the changing climate, the inflexibility in infrastructure and institutions that manage water, and the poor integration of all stakeholders and sectors in water resources management. This study investigates the challenges and opportunities in implementing integrated water resources management and its critical role towards climate change adaptation. A preliminary assessment of sustainable management of water resources and its role in effective climate change adaptation and resilience building in Kenya is carried out through questionnaire survey and stakeholder interactions. Climate change-induced uncertainty, diminishing water sources aggravated by growing water demand, weak institutional and financial governance, and lack of transparency and stakeholder inclusiveness are identified as the main challenging factors that need to be addressed to build a climate resilient society. The study furthermore emphasizes the critical role of water management in achieving Agenda 2030, the Paris Agreement on Climate Change, and the Sendai Framework for Disaster Risk Reduction.

\section{Keywords}

Climate change Water resources management - Climate change adaptation . Climate resilience $\cdot$ Sustainable development $\cdot$ Agenda 2030

\section{Introduction}

Our climate is changing and is affecting societies and their livelihoods (IPCC 2018). Climate change translates to water crisis in our everyday lives through the increasing uncertainty in water availability, decreasing water quality, and increasing competition over diminishing water resources (UN-Water 2019). According to the World Economic Forum's 2015 assessment of global risks, water crisis was ranked number one with the potential to severely affect poor and vulnerable population across countries and sectors (WEF 2015). As climate change impacts intensify and the populations and their water demands grow, water stress is likely to increase.

The International Food Policy Research Institute has warned the global community that if business-as-usual continues, by 2050, about 4.8 billion people and approximately half of the global grain production will be at risk because of water stress (Water Resources Group 2016). According to FAO (2013), the rate of increase in water use is more than twice the rate of increase in population during the last century. This increase in water use combined with climate change-induced uncertainty in water availability will aggravate the situation of regions that are already under water stress. 
This decade marked a surge in global floods and extreme rainfall events by more than $50 \%$ with an occurrence rate that is four times higher than in 1980 (EASAC 2018). According to the Organization for Economic Cooperation and Development (OECD) Environmental Outlook (OECD 2012), the number of people at risk from floods by 2050 is estimated to be about 1.6 billion, and the associated economic risk is expected to be around US\$ 45 trillion.

The UN World Water Development Report (WWAP 2019) findings show that the number of people affected and the number of people killed by water-related emergencies such as inadequate water and sanitation, droughts, and flooding are much higher than that due to earthquakes and epidemics and conflicts globally. According to EM-DAT (2019), during the past two decades, floods and droughts have caused more than 166,000 deaths leading to a total economic damage of about US\$700 billion.

In Africa, the increase in floods, droughts, and storms has severely affected the livelihoods of population through lack of safe and clean drinking water, crop failures, food shortages, lack of clean energy, etc. According to the World Bank report (2019), Africa has experienced increasing climate and water risks with more than 2,000 natural disasters since 1970, of which about 1,000 happened in the last decade. According to OECD (2012), between 75 and 250 million people in Africa are projected to be under increased water stress, and agricultural production can reduce by up to $50 \%$ in some regions by 2020 . The rainfall projections in Africa indicated that Southern Africa will become drier and Eastern and Western Africa will become wetter with increased risk of floods (UNDP 2018). The recent water crisis in South Africa, the food crisis in Sahel, and disastrous cyclones in Mozambique are reminders of society's vulnerability and unpreparedness in the wake of climate change reality, which in most of the cases are aggravated by incompetent institutional and financial capacities.

According to the UN Environment Adaptation Gap Finance Report (UNEP 2018), the global estimates of the costs of climate change adaptation in developing countries are between US $\$ 140$ billion and US $\$ 300$ billion by 2030 (which is two to three times higher than the earlier estimates cited in the Intergovernmental Panel on Climate Change [IPCC] report). By 2050, the estimates can plausibly be four to five times higher - US $\$ 280$ billion to US\$500 billion. For Africa, this would mean that the resources that would have otherwise directed for economic growth, to overcome poverty and to achieve the United Nations Sustainable Development Goals [SDGs] are now to be diverted toward climate change adaptation and resilience building initiatives.

\section{East African Community and Climate Change Impacts}

Climate model projections for East Africa indicate that rainfall and temperature will become extreme and intense in the future affecting both the quantity and quality of surface and groundwater in the region. This will severely affect the accessibility to 
safe and clean drinking water, health, food security, and energy resources (EAC and USAID 2018; Luwesi and Di Luyundi 2019). Adapting to these changes will require not only accurate knowledge of the frequency and severity of the extreme events but also planning and implementation of critical interventions to curb disasters across the East African Community (EAC). Moreover, this is highly important for the smooth implementation of the water targets of the African Union Agenda 2063, the Africa Water Vision 2025, and the 2030 Agenda for Sustainable Development, including the Kenya Vision 2030. The EAC has thus a long way to go for eliminating poverty, hunger, and food insecurity to give its citizens the right to healthy and productive lives.

\section{Kenya: Country Climate and Water Profile, Climate Change Impacts}

The National Water Policy of Kenya was developed in 1999 and based on that Water Act was established in 2002 (National Water Master Plan 2030 2013). The constitutional reforms of 2010 in Kenya introduced decentralization policy which came into effect in 2013 (Alexis and Lumbasi 2016). Since then the country has undergone significant transition through devolving governance to the 47 newly established counties. Moreover, the country's 2016 Climate Change Act formulated a comprehensive law and policy to guide national and subnational responses to climate change. The Water Resources Management Authority (WRMA) was reformed to Water Resources Authority (WRA) with a mandate that includes regulation, protection, and dissemination of information on water resources. Furthermore, WRA undertakes climate actions in terms of mitigation and adaptation to minimize the effects of global warming and climate change.

With the projected increase in temperature of about $2.5^{\circ} \mathrm{C}$ between 2000 and 2050 , and with rainfall becoming more intense and less predictable, Kenya is considered as very vulnerable to the impacts of climate change. The arid and semiarid lands (ASALs) in the north and the east of the country are particularly at risk because of the increased occurrence of drought and the associated food and water security challenges. The increased frequency of droughts, floods, and landslides in the Rift Valley Province and the increased floods and saltwater intrusion in the coastal areas are also posing challenges that demands efficient actions at national level to improve the adaptive capacity and resilience of the population (Government of the Netherlands 2019).

About $80 \%$ of the country's geographical area is arid or semiarid, and the main source of sustenance is pastoral and subsistence agriculture. The livelihoods of the poor are severely affected by the climate crisis and are having a severe impact on country's socioeconomic development (Mwendwa and Giliba 2012). A questionnaire survey conducted by Mwendwa and Giliba (2012) found recurrent droughts and changes in rainfall patterns to be the most important indicators of the effects of climate change and food shortage, hunger, famine, water scarcity, low yields, and high poverty levels as the most important impacts of climate change in Kenya. 
According to Ng'ang'a (2006), the 2004/2005 drought resulted in a prolonged famine in the less rainfall areas in the country. Decreasing lake surface area, for example, in the case of Lake Naivasha, has affected water quality, quantity, and navigability and has affected its biodiversity (Mironga 2005).

In urban areas, the impacts of climate change are visible mainly in informal settlements, where the risks arising from droughts and floods are severe. The risks in rural areas arise because of the dependence of rural population on the increasingly diminishing and degraded water sources. The major challenges faced by the periurban and rural population are the limited management capacity and low operating revenues. According to Mureithi et al. (2018), the lack of access to finance is also a major constraint as funding tends to be generally allocated to develop new water systems in very low-income areas with poor access rather than on restoring an already existing but poorly performing water supply scheme.

\section{Wise Water Management Toward Climate Change Adaptation}

It is crucial to acknowledge that water is not just a sector that has been impacted by climate change. The central role of water in adapting to the climate change-driven variations has been increasingly recognized over the past decade. However, water's ability to address climate change adaptation still faces many challenges. The inherent uncertainty associated with the changing climate, the inflexibility in infrastructure, and institutions that interact with water, in addition to the lack of an integrated approach in water resources management, are the fundamental challenges that need to be addressed at global, regional, and local scale (UN-Water 2019).

Water is inextricably linked with food and energy. Addressing climate change adaptation through effective water management is an opportunity by which the governance, infrastructure, and financing mechanisms can be transformed, leading to a holistic development of the community. It is highly important that the national policies should reflect on climate change adaptation strategies that are being followed in similar hydroclimatic parts of the world and at the same time incorporate the locally developed adaptation techniques to improve its climate resilience. Increased water stress coupled with increasing future water demands will require tough decisions on how to allocate water resources between competing water uses, including for climate change mitigation and adaptation.

Wise water management can be achieved through effective, efficient, and participatory management of water resources. Scarcity of water leading to drought can be addressed through increased rain water harvesting and water storage to capture the minimal available water at the source. These water harvesting structures will also aid in enhancing groundwater recharge, thereby improving the resilience of the society to future low surface water availability. In order to address the problems of excess water because of floods, the Water Resources Authority is in the process of developing plans to prepare the society towards flood disasters.

Application of innovative climate technology on the ground through sensor data, models, and weather forecasting improved water distribution systems, avoiding 
leakages and thereby decreasing loss through nonrevenue water are delivering positive outcomes. According to a recent report (Global Center on Adaptation 2019), researchers at Jomo Kenyatta University of Agriculture and Technology in Kenya in collaboration with Wageningen University and Research in the Netherlands is planning to launch the Climate Atlas, a localized weather monitoring system, with the aim of providing local rainfall and temperature projections across the 47 counties in Kenya for the period 2050-2100. The overall aim of this project is to protect Kenya's food supply for the future years. Another report by UNFCCC (2019) discussed a readiness proposal by Ghana on "Integrated Climate Monitoring and Early Warning System" aimed at strengthening the country's capacity to build an early warning system for droughts. In cities, nature-based solutions through restoration of degraded ecosystems in the buildup areas can improve the adaptive capacity. The city area can be envisaged as a catchment unit, and the effective capturing and managing of stormwater can make the city more resilient.

\section{Climate Resilience Through Water Management}

Adapting to climate change after the occurrence of a disaster is a reactive approach. Building resilience on the other hand is the ability to adapt to and transform and recover from that hazard in a timely, efficient, and sustainable manner. The first step towards achieving resilience is to have access to the relevant information, for example, through public campaign or by collaborating with established networks. Participatory vulnerability assessments at grassroots level are critical. Furthermore, resources should be available to make assessment and to ensure and facilitate processes leading to resilience. For instance, one need to prioritize the most critical climate change impact in a region based on the exposure, sensitivity, and adaptive capacity of the population to that impact. Based on that, a monitoring and evaluation system has to be designed and organizational capacity need to be build. Ensuring political commitment as well as facilitating implementation of public private partnerships can aid in short-term development of resilience. The final step is to develop necessary institutional arrangements that support long-term adaptation measures.

In Kenya, the relevant policy and legislative framework has been put in place to guide the country's response to the challenges of climate change. Climate change adaptation and resilience has been set in the National Adaptation Program (NAP) and is operationalized through the National Climate Change Action Plan (NCCAP). This is done by mainstreaming adaptation across all sectors in the national planning, budgeting and implementation processes, and taking cognizant of the fact that climate change is a cross-cutting sustainable development issue with economic, social, and environmental impacts (GoK 2016). The other policy documents include the National Drought Management Authority Act 2016, National Policy for Disaster Risk Management 2013, the National Climate Change Response Strategy (NCCRS) 2010, and the Climate Change Act 2016.

Climate resilience through effective water management can be achieved through sustainable implementation of integrated water resources management. Functional 
water governance mechanisms can reduce disasters and build capacity for adaptation and thereby improve resilience. Locally designed and implemented water storage and flood control structures and nature-based solutions, for instance, lakes as natural water storage structures and floodplains as natural excess runoff absorbers, are some examples on climate resilience through wise water management. Healthy ecosystem services are dependent on well-functioning river basins, which in turn can support agriculture and fisheries, wastewater treatment, drinking water provision, groundwater recharge, and coastal protection among others. In Zambia, the natural underground water reservoirs were protected through proper waste disposal, hence improving aquifer health and usage, thereby benefiting the local population in Lusaka (IWA 2019).

Building resilience through empowerment of the climate change-affected community has been reported in many parts of the world. One such example is the Osukuru United Women's Network in Uganda (Global Resilience Partnership 2019). The major climate change impact faced by this community was flooding and the associated displacements and health issues. This women's network initiated campaigns and improved the resilience of the community by building trenches around the houses to prevent floodwater from entering their homes. With more and more people joining this network, the success rate is high. However, there are challenges in the sustainable functioning of the network, for instance, financial viability, capacity building, training, mobility, etc. Enhanced climate resilience thus includes strong economic growth, resilient ecosystems, and sustainable livelihoods. It is noted that through climate financing (Odhengo et al. 2019) and public-private partnerships, there will be opportunities for progress in Kenya

The core approach in building resilience includes creating awareness, building social capital, improving technical capacities, and thereby empowering the community. Community-based vulnerability assessment and development of resilience action plan and promoting joint action through multi-stakeholder groups aid in faster adaptation. Furthermore, by making the livelihood-dependent economies diverse and flexible can also improve the community's resilience to climate change. Knowledge, learning, innovation, and clean technology are key towards achieving climate resilience. Smart agricultural technology such as integrated weather and market advisories inform farmers on what and when to grow and harvest, where to sell their produce, etc.

Questionnaire survey and stakeholder discussions including governmental, nongovernmental, and other organizations in Kenya are ongoing. According to the survey results, climate change impacts that are being experienced in the region are manifold - floods, droughts, storms, and its associated impacts on the society and the ecosystem. One major impact is on agriculture and food production, especially on the subsistence farming. Decline in agricultural produce has reduced the marginal GDP in the agriculture sector. This along with the fluctuations in world market prices and changes in geographical distribution of trade regimes has caused an increased number of people at risk of hunger and food security. Extreme weather conditions have affected water supply and water quality, thereby affecting human health. The increased demand coupled with the decreasing supply of source water resources has 
led to conflicts over water sharing. The timely dissemination of relevant climate information to the most vulnerable sections of the society is yet another major challenge that needs to be addressed.

The sustainable management of water resources faces major challenges because of climate change-induced uncertainty, diminishing water resources, increased water scarcity, and lack of protection of water sources through regulation. Community engagement and stakeholder participation especially from the vulnerable communities are crucial, and ownership and control of water resources are found to have resulted in more active participation of stakeholders. Incorporation and mainstreaming of innovation and technology are increasingly applied but have more scope for improvement. Climate change adaptation through rainwater harvesting, water storage development, and climate smart agriculture is followed by communities with support from government. The major constraint in the wise management of water resources is the long-term sustainable finance and funding mechanisms.

Kenya has identified climate change and disaster risk management as two of the three thematic areas in their National Plan. The nationally determined contributions (NDC) identify mainstreaming of climate change adaptation in the water sector as one of the priority adaptation strategies (Ministry of the Environment of the Republic of Kenya 2013). Adaptation strategies include development of water resources monitoring and early warning assessments.

\section{Water: A Cross-Cutting Factor in Agenda 2030 SDGs}

The achievement of Agenda 2030 Sustainable Development Goals are dependent on improved and sustainable water management (UNESCO and UN-Water 2020). There are multiple interlinkages of SDG 6 on water to the other 16 SDGs and also intralinkages within the SDG 6 connecting water and sanitation, water quantity and quality, IWRM, and community engagement in IWRM. The institutional and financial investment in achieving SDG 6 through resilient water management will inherently advance the progress of other SDGs through: overall poverty reduction (SDG 1); water security supporting the food and agriculture sector and thereby eradicating hunger (SDG2); quality water toward good health (SDG3); safe, segregated toilets and menstrual hygiene improves girls' access to education (SDG 4); gender equality in public and working life (SDG 5); access to energy and hydropower as one solution for sustainable energy (SDG 7); inclusive and productive economic growth and employment through water (SDG 8); resilient and sustainable water infrastructure (SDG 9); reduced inequalities through accelerated and inclusive action on water supply and sanitation (SDG10); sustainable and equitable urban development (SDG 11); equitable use and efficient water resources management (SDG 12); combating climate change impacts through climate-resilient water resources management (SDG 13); water quality and water resources management upstream on the land and along the rivers impacts coastal and marine ecosystem (SDG 14); increasing sustainable management of soil (SDG 15); promoting peaceful societies and accountable and inclusive institutions through effective water 
governance (SDG 16); and building commitments and accountability in the water sector, institutional coordination of water programs, mobilizing funding, and improved technology through strengthened means of implementation (SDG 17). Acknowledging the significance of water in these interlinkages and increasing efforts in addressing the challenges to achieve SDG 6 will automatically advance progress in climate change adaptation through wise water resources management and will help build resilient communities.

Although water is not explicitly mentioned in the Paris Agreement or in the Sendai Framework, it is important to acknowledge its relevance in achieving most of the mitigation and adaptation strategies and targets. The United Nations Framework Convention on Climate Change (UNFCCC) assessed the link between climate change and integrated water resources management such as watershed protection, waste- and stormwater management, water conservation, recycling, and desalination (UNFCCC 2019), where water governance is emerging as a leading domain for resilience to climate change.

\section{Conclusion}

Climate change primarily impacts society through several disasters, such as floods, droughts, storms, etc. which then severely affects human security and socioeconomic development of the region. Building and enhancing resilience to these disasters through effective water management are crucial, and water can play a major role in achieving effective climate change adaptation. Furthermore, disasters are recognized as opportunities to revitalize livelihoods, environment, and economies that can then lead to communities that are more resilient.

Innovative technologies in water supply and management and active participation of civil society, government, and private sectors can improve urban resilience. An integrated water resources management is imperative for attaining both rural and urban resilience as it safeguards their livelihoods and food security. It is also essential to ensure inclusiveness and meaningful participation of all stakeholders and include indigenous adaptation practices and traditional knowledge.

National and regional climate policy and planning should follow an integrated approach to climate change and water management. It is extremely important that the national adaptation strategies assist the vulnerable sections of the society and improve their resilience to the climate change impacts. Furthermore, increased investment is needed in institutions, capacity development, better data collection, assessment, and sharing.

\section{References}

Alexis S, Lumbasi L (2016) The impact of decentralization in Kenya, Trinity College London, Masters in Development Practice 2016, AidLink enabling communities in Africa tackle poverty

EAC, USAID (2018) Climate change vulnerability and adaptation in East Africa, current and future climate change. https://www.climatelinks.org/sites/default/files/asset/document/2018_USAID- 
PREPARED-TetraTech_VIA-East-Africa-Current-Future-CC-Factsheet.pdf. Accessed 27 Mar 2019

EASAC (European Academies' Science Advisory Council) (2018) Extreme weather events in Europe: preparing for climate change adaptation: an update on EASAC's 2013 study. https:// easac.eu/publications/details/extreme-weather-events-in-europe/

EM-DAT (Emergency Events Database) (2019) The emergency events database. Centre for Research on the Epidemiology of Disasters (CRED), Université catholique de Louvain, Brussels. www.emdat.be

FAO (2013) Coping with water scarcity: an Action framework for agriculture and food security. FAO water reports no. 38. FAO, Rome. www.fao.org/3/a-i3015e.pdf

Global Center on Adaptation (2019) How mapping changes on a local level will help Kentan farmers. https://gca.org/solutions/how-mapping-changes-on-a-local-level-will-help-kenyanfarmers?utm_sq=g9atrsd0w0. Accessed 27 Mar 2020

Global Resilience Partnership (2019) Thriving in the face of surprise, uncertainty and change, Resilience Insights 2019. http://grpinsightsreport.info/. Accessed 31 Oct 2019

GoK (2016) Kenya National Adaptation Plan: 2015-2030, Enhanced climate resilience towards the attainment of Vision 2030 and beyond, Government of Kenya, July 2016.

Government of the Netherlands (2019) Climate change profile, Kenya. Report by the Ministry of Foreign Affairs, Government of the Netherlands.

IPCC (2018) Summary for policymakers. Global warming of $1.5^{\circ} \mathrm{C}$. An IPCC special report on the impacts of global warming of $1.5^{\circ} \mathrm{C}$ above pre-industrial levels and related global greenhouse gas emission pathways, in the context of strengthening the global response to the threat of climate change, sustainable development, and efforts to eradicate poverty. IPCC, Geneva. www. ipcc.ch/sr15/chapter/spm/

IWA (2019) Nature-based solutions: the advantage of being a developing country. https://iwanetwork.org/nature-based-solutions-the-advantage-of-being-a-developing-country/. Accessed 30 Oct 2019

Luwesi CN, Di Luyundi TM (2019) A quick appraisal of the impact of environmental changes on undernutrition in Kenge Health Zone, DRC. Biomed J Sci Techn Res 18(3):19-26. https://doi. org/10.26717/BJSTR.2019.18.003145

Ministry of the Environment of the Republic of Kenya (2013) The National Water Master Plan 2030. The Republic of Kenya. https://wasreb.go.ke/national-water-master-plan-2030/

Mironga JM (2005) Environmental implications of water hyacinth infestation in Lake Naivasha, Kenya. In: 11th World lakes conference, Nairobi, Kenya, 31st October to 4th November 2005, Pp: 580 - 592, Proceedings Volume II, Ministry of Water and Irrigation International Lake Environment Committee.

Mureithi PM, Luwesi CN, Mutiso MN, Förch N, Nkpeebo AY (2018) Legal and market requirements for water finance. In: Beyene A, Luwesi, CN (eds) Africa: the Kenya water sector reforms case in innovative water finance in Africa, A guide for water managers, volume 1: water finance innovations in context. The Nordic Africa Institute, Uppsala, Sweden.

Mwendwa P, Giliba RA (2012) Climate change impacts and adaptation strategies in Kenya. Chin J Popul Resour Environ 10(4):22-29. https://doi.org/10.1080/10042857.2012.10685104

National Water Master Plan 2030 (2013) The project on the development of the National Water Master Plan 2030, final report volume 1, Executive summary

Ng'ang'a JK (2006) Climate change impacts, vulnerability and adaptation assessment in East Africa, UNFCCC African regional workshop on adaptation, 21-23 September 2006, Accra

Odhengo P, Atela J, Steele P, Orindi V, Imbali F (2019) Climate finance in Kenya: review and future outlook, discussion paper

OECD (2012) OECD environmental outlook to 2050, OECD Publishing. https://doi.org/10.1787/ 9789264122246-en. Accessed 30 Oct 2019

UNDP (2018) Climate change adaptation in Africa, UNDP synthesis of experiences and recommendations. UNDP/GEF, New York

UNEP (2018) The adaptation gap report 2018. United Nations Environment Programme (UNEP), Nairobi, Kenya. https://www.unenvironment.org/resources/adaptation-gap-report 
UNESCO, UN-Water (2020) United Nations World Water Development report 2020: water and climate change. UNESCO, Paris

UNFCCC (2019) How developing countries are scaling up climate technology action, Article 19 Nov 2019. https://unfccc.int/news/how-developing-countries-are-scaling-up-climate-technol ogy-action

UN-Water (2019) Climate change and water, UN-Water policy brief. https://www.unwater.org/ publications/un-water-policy-brief-on-climate-change-and-water/. Accessed 28 Oct 2019

Water Resources Group (2016) Annual report, Partnerships for transformation, water security partnerships for people, growth and the environment

WEF (2015) Global risks 2015, 10th edn. World Economic Forum. http://www3.weforum.org/docs/ WEF_Global_Risks_2015_Report15.pdf. Accessed 18 Nov 2019

World Bank (2019) This is what it's all about: building resilience and adapting to climate change in Africa. https://www.worldbank.org/en/news/feature/2019/03/07/this-is-what-its-all-about-build ing-resilience-and-adapting-to-climate-change-in-africa?cid=EXT_WBEmailShare_EXT. Accessed 31 Oct 2019

WWAP (2019) The United Nations World Water Development report 2019, Leaving no one behind, UNESCO World Water Assessment Programme. UNESCO, Paris

Open Access This chapter is licensed under the terms of the Creative Commons Attribution 4.0 International License (http://creativecommons.org/licenses/by/4.0/), which permits use, sharing, adaptation, distribution and reproduction in any medium or format, as long as you give appropriate credit to the original author(s) and the source, provide a link to the Creative Commons license and indicate if changes were made.

The images or other third party material in this chapter are included in the chapter's Creative Commons license, unless indicated otherwise in a credit line to the material. If material is not included in the chapter's Creative Commons license and your intended use is not permitted by statutory regulation or exceeds the permitted use, you will need to obtain permission directly from the copyright holder.

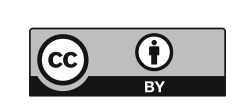

